\title{
The evaluation of seasonal fatty acid composition and food sources of Pileurobrachia pileus (Ctenophora) in terms of trophic marker fatty acids in the Southeastern Black Sea
}

\section{Güney Doğu Karadeniz'de Pleurobrachia pileus'un (Ctenophora) trofik işaret yağ asitleri açısından mevsimsel yağ asiti kompozisyonu ve besin kaynaklarının değerlendirilımesi}

\author{
Nurgül Şen Özdemir ${ }^{*}$ • Ali Muzaffer Feyzioğlu² • Fatma Caf ${ }^{3}$ \\ 1 Department of Veterinary Medicine, Vocational School of Technical Sciences, Bingöl University, 12000, Turkey \\ ${ }^{2}$ Department of Marine Sciences and Technology Engineering, Surmene Faculty of Marine Sciences, Karadeniz \\ Technical University, 61530, Trabzon, Turkey \\ ${ }^{3}$ Department of Veterinary Medicine, Vocational School of Technical Sciences, Bingöl University, 12000, Turkey
}

Ditps://orcid.org/0000-0001-6656-822X

https://orcid.org/0000-0003-1171-5493

https://orcid.org/0000-0002-0363-4848

Şen Özdemir, N., Feyzioğlu, A.M. \& Caf, F. (2021). The evaluation of seasonal fatty acid composition and food sources of Pileurobrachia pileus (Ctenophora) in terms of trophic marker fatty acids in the Southeastern Black Sea Ege Journal of Fisheries and Aquatic Sciences, 38(2), 211-218. DOI: 10.12714/egejfas.38.2.10

Abstract: Seasonal changes of the lipid and fatty acid composition of Pleurobrachia pileus investigated monthly from March 2012 to February 2013. Average total lipid content was determined as percentage (\%) and per individual (mg ind-1). It was highest in February $(1.48 \% ; 3.55 \mathrm{mg}$ ind-1). However, it was proportionally the lowest in April (0.40\%), and per individual in August ( $0.33 \mathrm{mg}$ ind-1). Major fatty acids of $P$. pileus were identified as 16:0, 14:0, 11:1 n-9c,

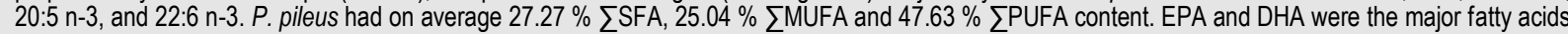
from PUFA. Seasonal changes of DHA were more obvious than EPA ( $p<0.05)$. Herbivore calanoid zooplankton trophic markers; $20: 1 \mathrm{n}-9$ and DHA/EPA and herbivory trophic markers; EPA and DHA content were high in P. pileus fatty acids. It showed that herbivory fatty acids were taken by feeding from herbivory zooplankton and phytoplankton. Diet was an important factor in seasonal fatty acid changes of $P$. pileus. In addition, we revealed that $P$. pileus has a rich lipid content and fatty acid composition and plays an important role in the Southeastern Black Sea ecosystem functionalities between herbivory and carnivory species.

Keywords: DHA, EPA, fatty acid, Southeastern Black Sea, Pileurobrachia pileus, trophic marker

Öz: Pileurobrachia pileus'un lipit ve yağ asiti kompozisyonunun mevsimsel değişimleri Mart 2012'den Şubat 2013'e kadar aylık olarak araştırımıştır. Ortalama toplam lipit içeriği yüzde $(\%)$ ve birey başına ( $\mathrm{mg}$ ind-1) olarak belirlenmiştir. Ortalama toplam lipit miktarı en yüksek şubat ayında bulunmuştur $(\%$ 1,48; 3,55 $\mathrm{mg}$ ind-1). Bununla birlikte, oransal en düsük miktar Nisan ayında $(\% 0,40)$ ve birey basıına Ağustos ayında $(0,33 \mathrm{mg}$ ind-1) belirlenmistir. $P$. pileus'taki en önemli yağ asitleri 16: 0, 14: 0, 11: $1 \mathrm{n}-9 \mathrm{c}, 20: 5 \mathrm{n}-3$ ve $22: 6 \mathrm{n}-3$ olarak tespit edilmiştir. $P$. pileus'da ortalama $\% 27,27 \sum$ SFA, $\% 25,04 \sum$ MUFA ve $\% 47,63$ ¿PUFA belirlenmiştir. EPA ve DHA'nın, başlıca PUFA yağ asitleri olduğu ve. DHA'da mevsimsel değişikliklerin EPA'dan daha belirgin olduğu saptanmıştır ( $p$ $<0,05)$. $P$. pileus yağ asitlerinde, herbivor kalanoid otçul zooplankton trofik işaretleri; $20: 1 \mathrm{n}-9$ ve DHA / EPA ve herbivor trofik işaretleri; EPA ve DHA içeriğinin yüksek olduğu tespit edilmisțir. Otçul yağ asitlerinin otçul zooplankton ve fitoplanktondan beslenerek alındığı görülmüștür. $P$. pileus'un mevsimsel yağ asiti değişiminde besinin önemli bir faktör olduğu saptanmıştır. Bunun yanında, $P$. pileus'un zengin bir lipit içeriğine ve yağ asiti bileşimine sahip olduğu ve Güneydoğu Karadeniz ekosisteminde, herbivor ve karnivor türler arasında önemli bir rol oynadığı ortaya konulmuştur.

Anahtar kelimeler: DHA, EPA, yağ asiti, Güney Doğu Karadeniz, Pileurobrachia pileus, trofik işaret

\section{INTRODUCTION}

Genus Pleurobrachia tentaculate ctenophores is common in coastal and neritic seas around of the world (Fraser, 1970; Frank, 1986; Mutlu et al., 1994, Mutlu and Bingel, 1999). Their diets have a wide range of prey (Hirota, 1974; Reeve \& Walter, 1978). Although their diets usually reflects the ambient in environment (Fraser, 1970; Mazlum et al., 2018), prey are likely to be selected on the basis of size and escape response (Greene et al., 1986). Pleurobrachia pileus from Pleurobrachia genus is a gelatinous planktonic carnivore Ctenophora, Tentaculata, Cydippida and a special tentacle feeder (Reeve and Walter, 1978). Copepods appear to be the main prey for ctenophores (Gibbons and Painting, 1992). It is known a little information about the role of ctenophores and other gelatinous zooplankton species in the energy flow in the marine ecosystems (Greene et al., 1986). In order to fully understand the energy flux through the foodwebs, detailed information about the bioenergetics of the organism is required (Møller et al., 2010). Lipids are important biochemical compounds in energy flows in marine food webs because they are rich in carbon with very high energy values (Parrish, 1988). Already, it was reported firstly by Lee et al.(1971) that fatty acids (FA) are an important lipid group are transferred from one 
trophic level to the next. Sargent and Whittle (1981); Sargent and Falk-Petersen (1988); Falk Petersen et al. (1990); Graeve et al. (1994); Stübing et al. (2003) suggested the potential of dietary fatty acids as food chain indicators and trophic markers. Similarly, fatty acids in consumer tissues can provide dietary information (Sargent et al., 1987; Graeve et al., 1994; Stübing et al., 2003), and some have been used successfully as trophic markers to monitor energy transfer to investigate prey-predator relationships (Falk-Peterson et al., 2004; Litzow et al., 2006). However, there are limited lipid studies about lipid amount and fatty acid composition of $P$. pileus. Therefore, we investigated seasonal changes of lipid amount and fatty acid composition of $P$. pileus, to determine the role of $P$. pileus in the functions between herbivorous and carnivorous species of the Southeastern Black Sea ecosystem. Additionally, it was thought that $P$. pileus generally carnivorous and feed on copepods in the Black Sea (Mutlu and Bingel, 1999; Mutlu, 2001; Birinci Özdemir et al., 2018). However, firstly, it was reported that phytoplankton was dominant group in the diet of $P$. pileus and zooplankton were the second dominant group in the Southeastern Black Sea by Mazlum et al. (2018). The fatty acids 16:I n-7 and 20:5 n-3 (Eicosapentaenoic Acid, EPA) as well as $18: 4 n-3$ and 22:6n-3 are characteristic of diatoms and dinoflagellates, respectively. 16:I n-7 and 18:4 n-3 fatty acids proved best-suited for trophic analyses, since their occurrence is most closely associated with the different phytoplankton groups ingested (Graeve et al., 1994). Therefore, we also aimed to evaluate the dietary composition of $P$. pileus using trophic marker fatty acids.

\section{MATERIAL AND METHODS}

The study was performed in the southern part of the Black Sea (Çamburnu Bay) at a station with coordinates $40^{\circ} 57^{\prime} 12^{\prime \prime}$ $\mathrm{N}^{\prime}-40^{\circ} 9^{\prime} 30^{\prime \prime} \mathrm{E}$. Samplings was made monthly from March 2012 to February 2013 aboard KTU's research vessel Yakamoz. Zooplankton samples were taken with a vertical haul with a $200 \mu \mathrm{m}$ mesh Hydro-Bios net with a mouth diameter of $110 \mathrm{~cm}$ from the depth of the upper border of the anoxic layer $130 \mathrm{~m}$ up to the surface layer.

Lipids were quantitatively extracted from the samples using chloroform/methanol with a mixing ratio of 2:1 Folch et al., (1957). Chloroform (2 mL) and $2 \mathrm{~N} \mathrm{NaOH}$ solution in methanol $(2 \mathrm{~mL})$ were used to determine fatty acid methyl esters (FAME). Then, $2 \mathrm{~mL}$ hexane was added on the restored dry lipid and the sample was transferred to a vial (Kates, 1986). The FAME were detected by gas Chromatography (Shimadzu GC-17 version 3 ). For the analysis, Capillary coumn had with a length of $25 \mathrm{~m}$, an inner diameter of $0.25 \mathrm{~mm}$ and a thickness of 25 $\mathrm{mm}$ (Permabond). $20 \mu \mathrm{l}$ samples were used to inject into the GC. The column temperature was set to $120-220{ }^{\circ} \mathrm{C}$ using increments of $5^{\circ} \mathrm{C} \mathrm{min}-1$ until $200^{\circ} \mathrm{C}$ and reached and $4^{\circ} \mathrm{C}$ $\mathrm{min}^{-1}$ to $220^{\circ} \mathrm{C}$. The column was kept for $8 \mathrm{~min}$ at $220^{\circ} \mathrm{C}$ and the total time was determined $35 \mathrm{~min}$. The injection temperature was $240^{\circ} \mathrm{C}$ and detector temperature was $280^{\circ} \mathrm{C}$. Nitrogen $\left(\mathrm{N}_{2}\right)$ was used as the carrier gas (Christie, 1990).

\section{Statistical analysis}

Datas were analyzed in STATISTICA 8.0. One-way variance analysis (ANOVA) was used in datas analysis. The comparisons among averages of the samples were carried out by using TUKEY test. TUKEY test created by post-hoc, homogenous groups $(p<0.05)$. Spearman Rank Correlation was used in definition of the statistical differences.

\section{RESULT AND DISCUSSION}

Fatty acid composition and total lipid amount of $P$. pileus were examined monthly from March 2012 to February 2013 in Southeastern Black Sea. Total lipid was determined in wet weight (WW) as percent (\%) and weight ( $\mathrm{mg} \mathrm{ind}^{-1}$ ). Lipid amount for most gelatinous zooplankton is low and they have about $95 \%$ water (Nelson et al., 2000). According to Larson and Harbison (1989) the average lipid amount of Antarctic gelatinous zooplankton is approximately $3 \%(0.4-6 \%)$, whereas Arctic gelatinous zooplankton have on average (8\%) lipid as a percent $1.5-22 \%$ in dry weight. In the study, the highest total lipid (\% ; mg ind-1) was obtained in February $\left(1.48 \% ; 3.55 \mathrm{mg}^{\text {ind }}{ }^{-1}\right.$, respectively). However, total lipid (\%) was the lowest in April ( $0.40 \%)$, while total lipid $\mathrm{mg} \mathrm{ind}^{-1}$ was the lowest in August (0.33 $\mathrm{mg}^{\text {ind- }}{ }^{-1}$ ) (Figure 1). Also, the average individual weight of $P$. pileus was the highest in September (220.39 $\left.\mathrm{mg} \mathrm{ind}^{-1}\right)$ and, the lowest in December (44.49 $\mathrm{mg} \mathrm{ind}^{-1}$ ).

It was reported that total lipid amount of $P$. pileus was 17 $\mathrm{mg} \mathrm{g}^{-1}$ in dry weight in North Sea by Hoeger (1983) and $3.4 \mathrm{mg} \mathrm{g}^{-1}$ in the Black Sea by Anninsky et al. (2005). Nelson et al. (2000) emphasized that the total lipid amount in wet weight was very low in 153 jelly zooplankton $\left(0.1-5 \mathrm{mg} \mathrm{g}^{-1}\right)$ in Antarctic during January 1997 and February 1998. Also, they reported that the total lipid amount of $P$. pileus was $3.6 \mathrm{mg} / \mathrm{g}$ in wet weight and $7.1 \%$ in dry weight. In this study, the average total lipid of $P$. pileus was $1.26 \mathrm{mg}^{\text {ind }}{ }^{-1}$. If we used gram instead of individual, total lipid amount will be $7.47 \mathrm{mg} \mathrm{g}^{-1}$ in wet weight. We thought that the differences in results of the studies can be derived from regional, seasonal and environmental differences. Especially, we thought that prey/diet in the environment can cause these differences. Phleger et al. (1998) indicated that lower lipid levels of gelatinous predators probably reflect lower lipid in their prey in Antarctic. Gelatinous macrozooplankton group mainly feeds on zooplankton, fish eggs and larvae in the Black Sea (Mutlu, 2001; Birinci Özdemir et al., 2018). Copepods were the most important group among of the digested food of $P$. pileus. Copepods have $47.2 \%$ of the total number of the digested food (Yip, 1984). Mutlu and Bingel (1999) reported that the stomach contents of $P$. pileus consisted mainly of Copepoda $90 \%$. However, Mazlum et al. (2018) indicated that seasonal diet of $P$. pileus is mainly phytoplankton in autumn and winter periods in Southeastern Black Sea. Calanus euxinus has the highest proportion 39\% in copepoda of the Southeastern Black Sea. Therefore, especially C. euxinus lipids can be an important effective on lipid levels of $P$. pileus. Also, phytoplankton lipids consumed directly by $P$. pileus; and phytoplankton lipids that 
the calanus often prefer as diet can affect lipids of $P$. pileus. Total lipid amount of $C$. euxinus from copepoda is the highest in February $7.03 \%$ (WW). Also, C. euxinus reaches the highest abundance in February (847 ind $\mathrm{m}^{-3}$ ) between March 2012 and February 2013 in the Southeastern Black Sea (Sen Ozdemir et al., 2017). We determined the highest lipid amount in the same season and sampling period for $P$. pileus (Figure 1).

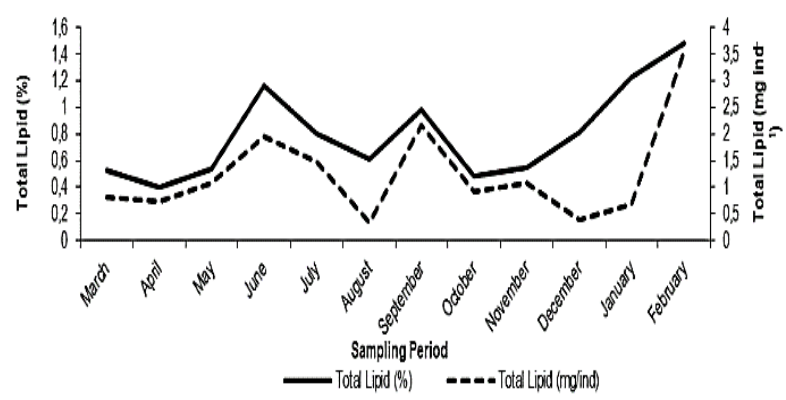

Figure 1. Total lipid variations $\left(\% ; \mathrm{mg} \mathrm{ind}^{-1}\right)$ of $P$. pileus during the sampling period

In this study, average total saturated fatty acids ( $\sum$ SFA) were $27.27 \%$ in the during sampling period. 16:0 (palmitic acid), 14:0 (myristic acid) and 18:0 (stearic acid) were the major SFA in P. pileus. 14:0,16:0 and 18:0 were the lowest in November (2.08\%; 9.97\%; 3.13\%, respectively) (Table 1). However, while 16:0 and 18:0 were the highest in September (19.29\%; $14.64 \%$, respectively), 14:0 was the highest in December $(8.17 \%)$. There was no statistically significant difference between seasons for 16:0 whereas there was statistically significant difference between seasons for $14: 0$ and 18:0 $(p<0.05)$ (Table 2). Whereas, 16:0 was the lowest in spring $(11.76 \%)$ and 18:0 was the lowest in winter $(3.93 \%)$. $14: 0$ was the highest in winter $(6.83 \%)$ and $18: 0$ was the highest in autumn (7.66\%). Additionally, 14:0 was the lowest in autumn (4.02\%), whereas 16:0 was the highest in autumn (14.00\%). Nelson et al. (2000) found the same results for the major SFA of $P$. pileus. In their results, $14: 0$ was $5.4 \%, 16: 0$ was $25.8 \%$ and $18: 0$ was $20.0 \%$.

Average total monounsaturated fatty acids ( $\Sigma$ MUFA) were $25.04 \%$ during the sampling period. $18: 1 \mathrm{n}-9 \mathrm{c}$ (oleic acid) was the dominant MUFA and on average $14.19 \%$ for $P$. pileus. followed by palmitoleic acid (16:1 n-7) on average $4.85 \%$. Palmitoleic acid was the highest in April (7.56\%) and the lowest in July (3.27 \%). Oleic acid was the highest in November $(29.68 \%)$ and the lowest in January $(6.68 \%)$ (Table 3). It increased in autumn (21.57\%) and immediately decreased in winter $(7.53 \%)$ (Table 4). 16:1 n-7 is generally of diatom origin and together with 20:1 n-9 can be found in high proportions in planktonic systems (Reinhardt and Van Vleet, 1986; Pakhomov and Perissinotto, 1996). 20:1 n-9 is the herbivorous calanoid marker (Dalsgaard et al., 2003; Falk-Peterson et al., 2009; Şen Özdemir et al., 2019). It shows herbivor copepods comprised an important part of the predator's diet (Stowasser et al., 2012). The MUFA herbivorous calanoid fatty acid markers were associated most strongly with pelagic species and vertical migrators (Şen Özdemir et al., 2019).
Ctenephoras were characterized by moderate to high levels of polyunsaturated fatty acids (PUFA) (20-47\%) with exception of $P$. pileus (Nelson et al., 2000). Nelson et al., (2000) showed 21.1\% PUFA in P. pileus. Average PUFA of $P$. pileus was found $47.63 \%$ in the study. The high level can depend on PUFA content of prey. DHA and EPA were the most important fatty acids in PUFA. Seasonal changes of DHA was statistically important $(p<0.05)$. DHA and EPA were the highest in March (30.49\%; 16.68\%. respectively). However. DHA and EPA were the lowest in September (17.85\%; 7.98\%. respectively) (Table 5). EPA showed a significant decrease only in autumn $(9.15 \%)$. while the other seasons did not differ with similar values (Table 6 ). It was found that seasonal changes in DHA were more obvious than EPA $(p<0.05)$. When these findings show a parallelism with Nelson et al., (2000) in terms of the variety of fatty acids that have the highest portion in $P$. pileus. Carnivorous zooplankton are rich in PUFA than herbivorous crustaceans zooplankton (Cripps and Atkinson, 2000; Stevens et al., 2004). Yet another index of carnivory is the DHA/EPA (Dalsgaard et al., 2003). DHA/EPA is used to explain trophic relations. EPA is typically found in higher proportions in diatoms whereas dinoflagellates contain higher DHA relative EPA (Nelson et al., 2000). However this ratio also reflects the relative proportions of dinoflagellate to diatoms in the diets of herbivorous and omnivorous copepods (Viso and Marty, 1993). In the study, the average DHA/EPA reached the highest value in autumn (2.37) and summer (2.08) hot seasons and the lowest value in winter (2.01) and spring (1.76) cold seasons (Table 6). While dinoflagellate blooms are generally observed in summer, diatom blooms are observed generally in mid spring in the Southeastern Black Sea (Sahin et al., 2007). According to Mazlum et al., (2018) phytoplankton is the dominant food group in their diet followed by zooplankton. They did not mention the presence of diatoms in dietary analysis for $P$. pileus. However, diatoms marker EPA was one of the major fatty acids during all the sampling seasons in our results. This may be a proof that they received EPA via herbivorous zooplankton in the Southeastern Black Sea food chain. EPA can be transferred from herbivor zooplankton to $P$. pileus by food web. $P$. pileus had high proportion DHA/EPA. This can be show as a proof that $P$. pileus is mostly a carnivorous because DHA/EPA carnivory index. Additionally, we think that the presence of Calanus euxinus which constitutes the main food source of $P$. pileus can be effective on the nutritional habit of $P$. pileus. Sen Ozdemir et al., (2017) reported that $C$. euxinus was the lowest abundance in the spring and summer and highest abundance winter and chlorophyll-a which is as an indicator of phytoplankton abundance was the high especially in late spring and early summer in the same sampling station and during the same time periods. Also, Sagitta setosa and copepod species were the others food sources of $P$. pileus in the Southeastern Black Sea. Şen Özdemir et al., (2020) indicated that $S$. setosa and copepod species (nauplii and copepodites) had the highest abundance in spring and summer in the same station and same sampling periods. P. pileus may be preferred abundant phytoplankton as food rather than scarce copepod in these seasons. We understand that food sources changes depending on season and this effects food preference of $P$. pileus in the Southeastern Black Sea. Diet was an important factor in seasonal fatty acid changes of $P$. pileus. 
Özdemir et al., Ege Journal of Fisheries and Aquatic Sciences, 38(2), 211-218 (2021)

Table 1. SFA composition of $P$. pileus during the sampling period ( $\%$ total defined FAME)

\begin{tabular}{|c|c|c|c|c|c|c|c|c|c|c|c|c|}
\hline FA & March & April & May & June & July & August & September & October & November & December & January & February \\
\hline 14:0 & $5.12 \pm 0.25^{\text {bcd }}$ & $4.31 \pm 0.16^{\mathrm{def}}$ & $5.51 \pm 0.68^{\mathrm{bcd}}$ & $5.93 \pm 0.75^{\text {abcd }}$ & $5.65 \pm 0.17 \mathrm{bcd}$ & $4.67 \pm 1.01$ cde & $2.68 \pm 0.51^{\text {ef }}$ & $7.32 \pm 0.83^{\mathrm{ab}}$ & $2.08 \pm 0.07^{\mathrm{f}}$ & $8.17 \pm 0.88^{a}$ & $5.51 \pm 0.18^{\mathrm{bcd}}$ & $6.80 \pm 1.40^{\mathrm{abc}}$ \\
\hline 15:0 & - & - & $1.14 \pm 0.12^{\mathrm{a}}$ & - & - & - & - & - & - & - & - & $0.84 \pm 0.10^{\mathrm{a}}$ \\
\hline 16:0 & $12.52 \pm 0.77^{\mathrm{bc}}$ & $11.56 \pm 0.14^{\mathrm{bc}}$ & $11.21 \pm 1.14^{b c}$ & $10.94 \pm 1.05^{b c}$ & $13.98 \pm 0.53^{b}$ & $11.37 \pm 1.32^{b c}$ & $19.29 \pm 1.14^{a}$ & $12.76 \pm 0.06^{b c}$ & $9.97 \pm 1.02^{\mathrm{bcd}}$ & $13.09 \pm 0.66^{b c}$ & $11.81 \pm 0.73^{b c}$ & $12.58 \pm 0.50^{\mathrm{bc}}$ \\
\hline 17:0 & - & - & - & - & - & - & $1.11 \pm 0.06^{\mathrm{a}}$ & - & - & - & $0.81 \pm 0.14^{\mathrm{a}}$ & $0.95 \pm 0.02^{\mathrm{a}}$ \\
\hline 18:0 & $5.09 \pm 0.24^{b}$ & $4.41 \pm 0.24^{\mathrm{bc}}$ & $3.74 \pm 0.29^{\mathrm{bc}}$ & $4.56 \pm 0.96^{\mathrm{bc}}$ & $5.24 \pm 0.21^{b}$ & $5.07 \pm 0.71^{b}$ & $14.64 \pm 2.45^{\mathrm{a}}$ & $5.22 \pm 0.21^{b}$ & $3.13 \pm 0.14^{c}$ & $3.75 \pm 1.17^{\mathrm{bc}}$ & $4.09 \pm 0.03^{b c}$ & $3.94 \pm 0.52^{\mathrm{bc}}$ \\
\hline 20:0 & - & $1.04 \pm 0.05^{\mathrm{a}}$ & - & - & - & - & - & - & - & - & $1.42 \pm 0.60^{\mathrm{a}}$ & - \\
\hline 22:0 & $6.35 \pm 0.38^{b}$ & $3.24 \pm 0.80^{\mathrm{cd}}$ & $5.57 \pm 0.37^{\mathrm{b}}$ & $6.03 \pm 0.38^{\mathrm{b}}$ & - & - & $2.58 \pm 0.48^{d}$ & - & $8.71 \pm 0.65^{\mathrm{a}}$ & $5.32 \pm 0.43^{\mathrm{bc}}$ & - & $6.00 \pm 0.12^{b}$ \\
\hline$\sum$ SFA & $29.08 \pm 0.94^{\mathrm{bc}}$ & $24.55 \pm 0.69 \mathrm{de}$ & $27.17 \pm 0.39$ bcde & $27.46 \pm 0.96^{\mathrm{bcd}}$ & $24.87 . \pm 0.90$ cdef & $21.11 \pm 2.01^{\mathrm{f}}$ & $40.30 \pm 4.08^{\mathrm{a}}$ & $25.29 \pm 0.59$ cdef & $23.89 \pm 1.46^{\text {ef }}$ & $30.33 \pm 0.08^{\mathrm{b}}$ & $23.64 \pm 0.33^{\text {def }}$ & $31.11 \pm 0.80^{\mathrm{b}}$ \\
\hline
\end{tabular}

Means followed by different letters and letter groups in the same row are significantly different $t p<0.05$. $n=3$. values are means $\pm S D$

Table 2. Seasonally SFA composition of $P$. pileus during the sampling period ( $\%$ total defined FAME)

\begin{tabular}{|c|c|c|c|c|}
\hline FA & Spring & Summer & Autumn & Winter \\
\hline $14: 0$ & $4.98 \pm 0.61 \mathrm{ab}$ & $5.41 \pm 0.66^{\mathrm{ab}}$ & $4.02 \pm 2.87 \mathrm{~b}$ & $6.83 \pm 1.33^{a}$ \\
\hline 15:0 & $0.38 \pm 0.66^{a}$ & - & - & $0.28 \pm 0.49 a$ \\
\hline $16: 0$ & $11.76 \pm 0.68^{a}$ & $12.10 \pm 1.65^{a}$ & $14.00 \pm 4.78^{a}$ & $12.56 \pm 0.64$ \\
\hline 17:0 & - & - & $0.37 \pm 0.64^{a}$ & $0.59 \pm 0.51 \mathrm{ab}$ \\
\hline 18:0 & $4.42 \pm 0.68 \mathrm{ab}$ & $4.96 \pm 0.35^{\mathrm{ab}}$ & $7.66 \pm 6.13^{a}$ & $3.93 \pm 0.17 \mathrm{~b}$ \\
\hline 20:0 & $0.35 \pm 0.60^{\mathrm{a}}$ & - & - & $0.47 \pm 0.82^{a}$ \\
\hline 22:0 & $5.06 \pm 1.61^{\mathrm{a}}$ & $2.01 \pm 3.48^{a}$ & $3.76 \pm 4.47^{\mathrm{a}}$ & $3.78 \pm 3.46^{a}$ \\
\hline$\sum \mathrm{SFA}$ & $26.95 \pm 2.14^{a}$ & $24.48 \pm 1.46^{a}$ & $29.28 \pm 2.06^{a}$ & $28.36 \pm 2.09 \mathrm{a}$ \\
\hline
\end{tabular}

Means followed by different letters and letter groups in the same row are significantly different $t p<0.05 . n=3-9$. values are means $\pm S D$ 
The evaluation of seasonal fatty acid composition and food sources of Pileurobrachia pileus (Ctenophora) in terms of trophic marker fatty acids in the Southeastern Black Sea

Table 3. MUFA composition of $P$. pileus during the sampling period (\% total defined FAME)

\begin{tabular}{|c|c|c|c|c|c|c|c|c|c|c|c|c|}
\hline FA & March & April & May & June & July & August & September & October & November & December & January & February \\
\hline 15:1 & - & - & $1.56 \pm 0.16^{\mathrm{a}}$ & $1.66 \pm 0.40^{\mathrm{a}}$ & - & - & - & - & - & - & $0.95 \pm 0.081^{b}$ & $1.02 \pm 0.21^{b}$ \\
\hline $16: 1 n-7$ & $4.8 \pm 0.4^{\mathrm{bcd}}$ & $7.56 \pm 0.17^{a}$ & $5.93 \pm 0.41^{\mathrm{ab}}$ & $5.28 \pm 0.27 \mathrm{bc}$ & $3.27 \pm 0.27$ de & $5.03 \pm 0.95^{\mathrm{bcd}}$ & $3.41 \pm 0.47 \mathrm{de}$ & $5.31 \pm 0.52^{\mathrm{bc}}$ & $2.57 \pm 0.50^{\mathrm{e}}$ & $4.97 \pm 1.01 \mathrm{bcd}$ & $3.74 \pm 0.64$ cde & $6.38 \pm 0.50^{\mathrm{ab}}$ \\
\hline 17:1 & - & - & - & - & - & - & $0.97 \pm 0.05^{a}$ & - & - & - & $0.63 \pm 0.04^{b}$ & $1.03 \pm 0.12^{\mathrm{ab}}$ \\
\hline $18: 1 \mathrm{n}-9 c$ & $9.29 \pm 0.32^{d}$ & $14.68 \pm 0.41^{c}$ & $13.35 \pm 1.57^{c}$ & $15.55 \pm 1.51^{c}$ & $14.66 \pm 0.86^{c}$ & $15.48 \pm 1.32^{c}$ & $20.91 \pm 1.45^{b}$ & $14.10 \pm 1.18 c$ & $29.68 \pm 2.15^{a}$ & $7.69 \pm 0.64^{d}$ & $6.68 \pm 1.28^{d}$ & $8.24 \pm 0.58^{d}$ \\
\hline $20: 1 n-9$ & $4.35 \pm 0.68^{\mathrm{a}}$ & $2.25 \pm 0.16^{c}$ & $2.24 \pm 0.41^{c}$ & $2.53 \pm 0.13^{\mathrm{bc}}$ & $3.11 \pm 0.13^{\mathrm{abc}}$ & $4.43 \pm 0.60^{\mathrm{a}}$ & $2.67 \pm 0.26^{b c}$ & $3.14 \pm 0.39 \mathrm{abc}$ & $1.72 \pm 0.25^{b}$ & $3.84 \pm 0.30^{\mathrm{ab}}$ & $3.07 \pm 0.18^{\mathrm{abc}}$ & $2.76 \pm 0.22^{\mathrm{bc}}$ \\
\hline $20: 1 n-X$ & - & - & $4.74 \pm 0.64^{\mathrm{abc}}$ & $4.38 \pm 0.06^{\mathrm{bc}}$ & - & - & - & $3.66 \pm 0.19 c$ & - & $5.66 \pm 0.58^{a}$ & $4.92 \pm 0.69^{\mathrm{ab}}$ & $4.69 \pm 0.47 \mathrm{abc}$ \\
\hline$\sum$ MUFA & $18.44 \pm 1.329$ & $24.49 \pm 0.19$ cdef & $27.76 \pm 3.12^{\mathrm{bc}}$ & $29.40 \pm 3.87^{\mathrm{ab}}$ & $21.04 \pm 1.17^{\text {efg }}$ & $24.93 \pm 2.80^{\text {bcde }}$ & $27.95 \pm 0.11^{\mathrm{bc}}$ & $26.22 \pm 0.81 \mathrm{bcd}$ & $34.64 \pm 1.9 \mathrm{a}$ & $22.16 \pm 1.14$ defg & $19.99 \pm 2.36^{\text {fg }}$ & $24.12 \pm 0.75^{\text {cdef }}$ \\
\hline
\end{tabular}

Means followed by different letters and letter groups in the same row are significantly different $p<0.05 . n=3$. values are means $\pm S D$

Table 4. Seasonally MUFA composition of $P$. pileus during the sampling period (\% total defined FAME)

\begin{tabular}{|c|c|c|c|c|}
\hline FA & Spring & Summer & Autumn & Winter \\
\hline 15:1 & $0.52 \pm 0.90 \mathrm{a}$ & $0.55 \pm 0.96^{\mathrm{a}}$ & - & $0.66 \pm 0.57 \mathrm{a}$ \\
\hline $16: 1 n-7$ & $6.07 \pm 1.39 a$ & $4.53 \pm 1.09^{a b}$ & $3.76 \pm 1.07^{b}$ & $5.03 \pm 1.32^{\mathrm{ab}}$ \\
\hline 17:1 & - & - & $0.32 \pm 0.56^{b}$ & $0.59 \pm 0.52^{\mathrm{a}}$ \\
\hline $18: 1 n-9 c$ & $12.44 \pm 2.81^{b}$ & $15.23 \pm 0.49 b$ & $21.57 \pm 7.81^{a}$ & $7.53 \pm 0.79 c$ \\
\hline $20: 1$ n-9 & $2.95 \pm 1.22^{\mathrm{a}}$ & $3.35 \pm 0.97^{a}$ & $2.51 \pm 0.71^{\mathrm{a}}$ & $3.22 \pm 0.56^{a}$ \\
\hline 20:1 n-X & $1.58 \pm 2.73^{b}$ & $1.46 \pm 2.53^{b}$ & $1.22 \pm 2.11^{\mathrm{b}}$ & $5.09 \pm 0.51^{a}$ \\
\hline$\sum$ MUFA & $23.56 \pm 4.73^{b}$ & $25.12 \pm 4.18^{\mathrm{ab}}$ & $29.38 \pm 4.45^{a}$ & $22.09 \pm 2.07 \mathrm{~b}$ \\
\hline
\end{tabular}

Means followed by different letters and letter groups in the same row are significantly different $t p<0.05$. $n=9$. values are means $\pm S D$ 
Özdemir et al., Ege Journal of Fisheries and Aquatic Sciences, 38(2), 211-218 (2021)

Table 5. PUFA composition of $P$. pileus during the sampling period (\% total defined FAME)

\begin{tabular}{|c|c|c|c|c|c|c|c|c|c|c|c|c|}
\hline FA & March & April & May & June & July & August & September & October & November & December & January & February \\
\hline $18: 2 n-6 t$ & - & - & - & - & - & - & - & - & - & - & - & $0.90 \pm 0.02$ \\
\hline $18: 2 n-6 c$ & $5.31 \pm 0.17 \mathrm{def}$ & $3.71 \pm 0.65^{f}$ & $5.70 \pm 0.55^{\mathrm{def}}$ & $6.32 \pm 1.20_{\text {cdef }}$ & $13.64 \pm 0.86^{b}$ & $8.87 \pm 1.53^{\mathrm{c}}$ & $6.88 \pm 1.37$ cde & $7.53 \pm 0.84^{\mathrm{cd}}$ & $17.29 \pm 1.56^{\mathrm{a}}$ & $3.79 \pm 0.17^{f}$ & $4.41 \pm 0.0 g_{\text {ef }}$ & $5.42 \pm 0.83^{\text {def }}$ \\
\hline $18: 3 n-3 c$ & - & $1.57 \pm 0.07^{\mathrm{a}}$ & $1.63 \pm 0.19 \mathrm{a}$ & $1.53 \pm 0.21^{\mathrm{a}}$ & - & - & - & $0.96 \pm 0.51^{b}$ & - & - & $1.28 \pm 0.13^{\mathrm{ab}}$ & $1.02 \pm 0.03^{b}$ \\
\hline $20: 2 n-6$ & - & $4.25 \pm 0.23^{a}$ & - & - & - & - & - & - & - & - & $3.65 \pm 1.03^{b}$ & - \\
\hline $20: 3 n-6$ & - & $1.35 \pm 0.26$ & - & - & - & - & - & - & - & - & - & - \\
\hline $20: 4 n-3$ & - & $2.78 \pm 0.26^{b}$ & - & - & - & $5.52 \pm 0.56^{a}$ & - & - & - & - & $1.36 \pm 0.31^{\mathrm{c}}$ & - \\
\hline $20: 4 n-6$ & - & $1.41 \pm 0.04 \mathrm{e}$ & - & - & - & - & - & - & - & - & - & - \\
\hline $22: 2$ & - & - & - & - & - & - & - & - & - & - & $3.10 \pm 0.62$ & - \\
\hline 20:5 n-3(EPA) & $16.68 \pm 0.51^{\mathrm{a}}$ & $13.40 \pm 0.22^{b}$ & $13.72 \pm 0.48^{b}$ & $12.54 \pm 1.29 b$ & $12.51 \pm 0.99 \mathrm{~b}$ & $12.38 \pm 0.70^{b}$ & $7.98 \pm 1.55^{c}$ & $12.68 \pm 0.45^{b}$ & $6.80 \pm 1.57 c$ & $14.07 \pm 0.84 \mathrm{ab}$ & $13.21 \pm 0.85^{b}$ & $14.32 \pm 0.98 \mathrm{ab}$ \\
\hline 22:6n-3(DHA) & $30.49 \pm 2.10^{\mathrm{a}}$ & $22.50 \pm 0.60$ cde & $23.99 \pm 1.13 \mathrm{bcd}$ & $22.73 \pm 2.52$ cde & $27.96 \pm 1.81 \mathrm{abc}$ & $27.20 \pm 1.18 \mathrm{abc}$ & $17.85 \pm 3.62^{\mathrm{e}}$ & $27.33 \pm 0.83 \mathrm{abc}$ & $18.05 \pm 1.51^{\mathrm{de}}$ & $29.60 \pm 1.50^{\mathrm{ab}}$ & $29.36 \pm 0.77 \mathrm{ab}$ & $23.77 \pm 1.34 \mathrm{bcde}$ \\
\hline$\sum$ PUFA & $52.48 \pm 2.28^{\mathrm{ab}}$ & $50.96 \pm 0.53 \mathrm{abc}$ & $45.04 \pm 1.84^{\mathrm{cde}}$ & $43.12 \pm 2.95^{\mathrm{de}}$ & $54.11 \pm 2.01^{a}$ & $53.96 \pm 0.85^{a}$ & $32.71 \pm 6.32^{f}$ & $48.50 \pm 0.31 \mathrm{abcd}$ & $42.14 \pm 3.20^{\mathrm{e}}$ & $47.50 \pm 1.06$ bcde & $56.38 \pm 2.44^{\mathrm{ab}}$ & $46.77 \pm 1.48 \mathrm{de}$ \\
\hline DHA/EPA & $1.82 \pm 0.13^{b}$ & $1.68 \pm 0.02^{b}$ & $1.75 \pm 0.04^{b}$ & $1.81 \pm 0.13^{b}$ & $2.23 \pm 0.03^{\mathrm{ab}}$ & $2.20 \pm 0.07 a b$ & $2.24 \pm 0.15^{\mathrm{ab}}$ & $2.16 \pm 0.09 \mathrm{ab}$ & $2.72 \pm 0.23^{a}$ & $2.11 \pm 0.22^{\mathrm{ab}}$ & $2.22 \pm 0.04 \mathrm{ab}$ & $1.67 \pm 0.20^{b}$ \\
\hline
\end{tabular}

Means followed by different letters and letter groups in the same row are significantly different $t p<0.05$. $n=3$. values are means $\pm S D$

Table 6. Seasonally PUFA composition of $P$. pileus during the sampling period (\% total defined FAME)

\begin{tabular}{|c|c|c|c|c|}
\hline FA & Spring & Summer & Autumn & Winter \\
\hline $18: 2 n-6 t$ & - & - & - & $0.30 \pm 0.17$ \\
\hline $18: 2 n-6 c$ & $4.91 \pm 1.05^{b}$ & $9.61 \pm 3.69^{a}$ & $10.57 \pm 5.83^{a}$ & $4.54 \pm 0.82^{b}$ \\
\hline $18: 3 \mathrm{n}-3 c$ & $1.07 \pm 0.04^{a}$ & $0.51 \pm 0.21^{a}$ & $0.32 \pm 0.51^{\mathrm{a}}$ & $0.76 \pm 0.18^{a}$ \\
\hline $20: 2 n-6$ & $1.42 \pm 0.23^{a}$ & - & - & $1.22 \pm 1.03^{a}$ \\
\hline $20: 3 n-6$ & $0.45 \pm 0.26$ & - & - & - \\
\hline $20: 4 n-3$ & $0.93 \pm 0.26^{a}$ & $1.84 \pm 0.56^{a}$ & - & $0.45 \pm 0.31^{a}$ \\
\hline $20: 4 n-6$ & $0.47 \pm 0.27$ & - & - & - \\
\hline $22: 2$ & - & - & - & $1.03 \pm 0.59^{a}$ \\
\hline 20:5 n-3(EPA) & $14.60 \pm 1.81^{a}$ & $12.48 \pm 0.09 \mathrm{a}$ & $9.15 \pm 3.11^{b}$ & $13.87 \pm 0.58^{a}$ \\
\hline 22:6 n-3 (DHA) & $25.66 \pm 4.25 \mathrm{ab}$ & $25.96 \pm 2.83 \mathrm{ab}$ & $21.08 \pm 5.42^{b}$ & $27.59 \pm 3.30^{a}$ \\
\hline$\sum$ PUFA & $49.50 \pm 3.93^{a}$ & $50.40 \pm 6.30^{\mathrm{a}}$ & $41.12 \pm 7.94^{b}$ & $49.50 \pm 5.35^{a}$ \\
\hline DHA/EPA & $1.76 \pm 0.07^{b}$ & $2.08 \pm 0.24 \mathrm{ab}$ & $2.37 \pm 0.30^{\mathrm{ab}}$ & $2.01 \pm 0.29 \mathrm{a}$ \\
\hline
\end{tabular}




\section{CONCLUSION}

$P$. pileus has a rich lipid content and fatty acid composition. It plays an important role in the Southeastern Black Sea ecosystem functionalities between herbivory and carnivory species. Calanoid herbivory markers 20:1 n-9 and DHA/EPA and herbivory marker EPA and DHA content were high in fatty acids of $P$. pileus. We showed that although $P$. pileus mostly carnivorous, it had herbivorous fatty acid markers. Herbivory fatty acids were taken by feeding from herbivory species and phytoplankton (dinoflagellates and diatoms) especially when

\section{REFERENCES}

Anninsky, B.E., Finenko, G.A., Abolmasova, G.I., Hubareva, E.S., Svetlichny, L.S., Bat, L. \& Kideys, A.E. (2004). Effect of starvation on the biochemical compositions and metabolic rates of ctenophores Mnemiopsis leidyi and Beroe ovata in the Black Sea. Journal of Marine Biology Association United Kingtom, 85, 549-561. DOI: 10.1017/S0025315405011471

Birinci Özdemir, Z., Erdem, Y. \& Bat, L. (2018). Food composition and distribution of gelatinous macrozooplankton in the southern Black Sea Indian Journal of Geo Marine Sciences, 4712, 2541-2548.

Christie, W.W. (1990). Gas chromatography and lipids. (pp 302-320). The Oil Press. Glasgow.

Cripps, G.C. \& Atkinson, A. (2000). Fatty acid composition as an indicator of carnivory in Antarctic krill, Euphausia superba. Canadian Journal of Fisheries Aquatic Sciences, 57(S3), 31-37. DOI:10.1139/f00-167

Dalsgaard, J., St John, M., Kattner, G., Muller-Navarra, D. \& Hagen, W. (2003). Fatty acid trophic markers in the pelagic marine environment. Advances Marine Biology, 46, 225-340. DOI: 10.1016/s0065-2881(03)46005-7

Falk-Petersen, S., Hopkins, C.C.E. \& Sargent, J.R. (1990). Trophic relationships in the pelagic arctic food web. In M. Barnes. R.N. Gibson (Eds). Trophic relationships in the marine environment (pp 315-333). Proc. 24th Europ Mar Biol Symp. Aberdeen: Aberdeen University Press.

Falk-Petersen, S., Haug, T., Nilssen, K.T., Wold, A. \& Dahl, T.M. (2004). Lipids and trophic linkages in harp seal Phoca groenlandica from the eastern Barents Sea. Polar Research, 23, 43-50. DOI: 10.1111/j.1751-8369.2004.tb00128

Falk-Petersen, S., Mayzaud, P., Kattner, G. \& Sargent, J.R (2009). Lipids and life strategy of Arctic Calanus. Marine Biology Research, 5(1), 18-39. DOI: $10.1080 / 17451000802512267$

Folch, J., Lees, M. \& Sloane-Stanley, G.H. (1957). A Simple Method for the Isolation and Purification of Total Lipides from Animal Tissues. The Journal of Biological Chemistry, 226, 497-509. DOI: 10.1016/S0021-9258(18)64849-5

Frank, K.T. (1986). Ecological significance of the ctenophore Pleurobrachia pileus off southwestern Nova Scotia. Canadian Journal of Fisheries and Aquatic Sciences, 431, 211-222. DOI: 10.1139/f86-024

Fraser, J.H. (1970). The ecology of the ctenophore Pleurobrachia pileus in Scottish waters. Journal du Conseil / Conseil Permanent International pour l'Exploration de la Mer, 332, 149-168. DOI: 10.1093/icesjms/33.2.149

Gibbons, M.J. \& Painting, S.J. (1992). The effects and implications of container volume on clearance rates of the ambush entangling predato Pleurobrachia pileus Ctenophora: Tentaculata. Journal of Experimental Marine Biology and Ecology, 163, 199-208. DOI: 10.1016 / 0022-0981 (92) 90049-G

Graeve, M.G., Kattner, G. \& Hagen, W. (1994). Diet-induced changes in the fatty acid composition of Arctic herbivorous copepods: Experimental evidence of trophic markers. Journal of Experimental Marine Biology and Ecology, 182, 97-110. DOI: 10.1016/0022-0981(94)90213-5 zooplankton are low abundance in the Southeastern Black Sea ecosystem.

\section{ACKNOWLEDGEMENTS}

We thank research assistant Ümit Dokuzparmak, the crew of KTU YAKAMOZ for help in collection of the samples and Prof. Dr. Ökkeş Yılmaz for his help with GC analyses. This work was a part of PhD study supported by KTU BAP. 2010.117.001.9.

Greene, C.H. Landry M.R \& Monger, B.C (1986). Foraging behaviour and prey selection by the ambush entangling predator Pleurobrachia bachei. Ecology, 67, 1493-1501. DOI: 10.2307/1939080

Hirota, J. (1974). Quantitative natural history of Pleurobrachia bachei in La Jolla Bight. Fishery Bulletin-Washington, 722, 295-335.

Hoeger, U. (1983). Biochemical composition of ctenophores. Journal of Experimental Marine Biology and Ecology, 72, 251-261. DOI: 10.1016/0022-0981(83)90110-7

Kates, M. (1986). Techniques of lipidology: isolation, analysis, and identification of lipids, 2nd edn. Amsterdam. New York: Elsevier. New York : Elsevier Science Pub Co Laboratory Techniques in Biochemistry and Molecular Biology, 32, 464.

Larson, R.J. \& Harbison, G.R. (1989). Source and fate of lipids in polar gelatinous zooplankton. Arctic, 42, 339-346. DOI: 0.14430/arctic1675

Lee, R.F., Hirota, J. \& Barnett, A.M. (1971). Distribution and importance of wax esters in marine copepods and other zooplankton. Deep Sea Research, 18, 1147-1165. DOI: 10.1016/0011-7471(71)90023-4

Litzow, M.A., Bailey, K.M., Prahl, F.G. \& Heinz, R. (2006). Climate regime shifts and reorganization of fish communities: the essential fatty acid limitation hypothesis. Marine Ecology Progress Series, 315, 1-11. DOI: 10.3354 / meps315001

Mazlum, R.E., Aytan, U. \& Agirbas, E. (2018). The feeding behaviour of Pleurobrachia pileus (ctenophora: tentaculata) in the Southeastern Black Sea: in relation to area and season. Fresenius Environmental Bulletin, 27(2), 871-879.

Mutlu, E., Bingel, F., Gücü, A.C., Melnikov, V.V., Niermann, U., Ostr, N.A. \& Zaika, V.E. (1994). Distribution of the new invader Mnemiopsis sp. and the resident Aurelia aurita and Pleurobrachia pileus populations in the Black Sea in the years 1991-1993. ICES Journal of Marine Sciences, 51 407-421. DOI: 10.1006/jmsc.1994.1042

Mutlu, E. \& Bingel, F. (1999). Distribution and abundance of ctenophores. and their zooplankton food in the Black Sea. I. Pleurobrachia pileus. Marine Biology. 135. 589-601. DOI: 10.1007/s00227005066

Mutlu, E. (2001). Distribution and abundance of moon jellyfish Aurelia aurita and its zooplankton food in the Black Sea. Marine Biology, 138, 329-339. DOI: 10.1007 / s002270000459

Møller, L.F., Canon, J.M. \& Tiselius, P. (2010). Bioenergetics and growth in the ctenophore Pleurobrachia pileus. Hydrobiologia, 645, 167-178. DOI: 10.1007 / s10750-010-0219-6

Nelson, M.M., Phleger, C.F., Mooney, B.D. \& Nichols, P.D. (2000). Lipids of Gelatinous Antarctic Zooplankton: Cnidaria and Ctenophora. Lipids, 35 (5), 551-559. DOI: 10.1007/s11745-000-555-5

Pakhomov, E.A. \& Perissinotto, R. (1996). Trophodynamics of the hyperiid amphipod Themisto gaudichaudii in the South Georgia region during late austral summer. Marine Ecology Progress Series, 134, 91-100. DOI: $10.3354 /$ meps134091 
Parrish, C.C. (1988). Dissolved and particulate marine lipid classes: a review. Marine Chemistry, 23, 17-40. DOI: $10.1016 / 0304-4203(88) 90020-5$

Phleger,C.F., Nichols, P.D. \& Virtue, P. (1998). Lipids and trophodynamics of Antarctic zooplankton. Comparative Biochemistry and Physiology, 120B 311-323. DOI: 10.1016/S0305-0491(98)10020-2

Reeve, M.R. \& Walter, M.A. (1978). Nutritional ecology of ctenophores - a review of recent research. Advances in Marine Biology, 15, 249-287. DOI: 10.1016/S0065-2881(08)60406-X

Reinhardt, S.B. \& Van Vleet, E.S. (1986). Lipid composition of twenty-two species of Antarctic midwater zooplankton and fish. Marine Biology, 91 149-159. DOI: 10.1007/BF00569431

Sahin, F., Bat, L., Ustun, F., Birinci Ozdemir, Z., Satilmis, H. H., Kideys, A.E. \& Develi, E.E. (2007). The Dinoflagellate- Diatom ratio in the Southeastern Black Sea off Sinop in the Years 1999-2000. Rapp. Comm. Int. Mer Médit, 38, 388.

Sargent, J.R, \& Whittle, K.J. (1981). Lipids and hydrocarbons in the marine food web. In A.R Longhurst. (Ed). Analysis of marine ecosystems (pp 491 533). London: Academic Press.

Sargent, J.R., Parkes, R J., Mueller-Harvey, I. \& Henderson, R.J. (1987). Lipid biomarkers in marine ecology. In M.A. Sleigh (Ed). Microbes in the Sea (pp 119-138). Harwood: Chichester.

Sargent, J.R. \& Falk-Petersen, S. (1988). The lipid biochemistry of calanoid copepods. Hydrobiologia, 167-168, 101-114. DOI: 10.1007/BF00026297

Sen Ozdemir, N., Feyzioglu, A.M., Caf, F. \& Yildiz, I. (2017). Seasonal changes in abundance. lipid and fatty acid composition of Calanus euxinus in the South-eastern Black Sea. Indian Journal of Fisheries, 643, 55-66. DOI:10.21077/ijf.2017.64.3.62172-09
Stevens, C.J., Deibel, D. \& Parrish, C.C. (2004). Incorporation of bacterial fatty acids and changes in a wax ester-based omnivory index during a longterm incubation experiment with Calanus glacialis Jaschnov. Journal of Experimental Marine Biology and Ecology, 303, 135-156. DOI: 10.1016 / j.jembe.2003.11.008

Stowasser, G., Pond D.W. \& Collins, M.A. (2012). Fatty acid trophic markers elucidate resource partitioning within the demersal fish community of South Georgia and Shag Rocks Southern Ocean. Marine Biology, 159, 2229-2310. DOI: 10.1007/s00227-012-2015-5

Stübing, D., Hagen, W. \& Schmidt, K. (2003). On the use of lipid biomarkers in marine food web analyses: An experimental case study on the Antarctic krill. Euphausia superba. Limnology and Oceanography, 484, 1685-1700. DOI: 10.4319/lo.2003.48.4.1685

Sen Özdemir, N., Parrish, C.C., Parzanini, C.C. \& Mercier, A. (2019). Neutral and polar lipid fatty acids in five families of demersal and pelagic fish from the deep Northwest Atlantic. ICES Journal of Marine Science, 76 (6), 1807-1815. DOI:10.1093/icesjms/fsz054

Şen Özdemir, N., Feyzioglu, A.M., Caf, F. \& Yildiz, I. (2020). Can the early stages copepoda (copepodites and naupliies) abundances effect the fatty acid composition of Sagitta setosa (chaetognatha) in the southeastern Black Sea? Ege Journal of Fisheries and Aquatic Sciences, 37 (4),335342. DOI: 10.12714/egejfas.37.4.03

Viso, A. C. \& Marty, J. C. (1993). Fatty acids from 28 marine microalgae. Phytochemistry, 34, 1521-1533. DOI: 10.1016/S0031-9422(00)90839-2

Yip, S. Y. (1984). The Feeding of Pleurabranchia pileus Müller (Ctenephora) from Galbay Bay. Proceedings of the Royal Irish Academy, 84 (B), 109122. 